\title{
The effects of listening to classical music on dehydroepiandrosterone sulfate and subjective anxiety levels in female in-patients with psoriasis
}

\author{
Wpływ muzyki klasycznej na stężenie siarczanu dehydroepiandrosteronu \\ i subiektywny poziom lęku u hospitalizowanych pacjentek z łuszczycą
}

\author{
Olivia Krasiński-Heringa', Witold Owczarek², Magdalena Kozłowska', Alicja Ograczyk-Piotrowska \\ Igor Bednarski', Anna Zalewska-Janowska³, Joanna Narbutt' \\ 'Dermatology, Pediatric Dermatology and Oncology Department, Medical University of Lodz, Poland \\ 2Department of Dermatology, Military Institute of Medicine, Warsaw, Poland \\ ${ }^{3}$ Department of Psychodermatology, Medical University of Lodz, Poland \\ ${ }^{3}$ Klinika Dermatologii, Dermatologii Dziecięcej i Onkologicznej Uniwersytetu Medycznego w Łodzi, Polska \\ ${ }^{2}$ Klinika Dermatologiczna Wojskowego Instytutu Medycznego w Warszawie, Polska \\ ${ }^{3}$ Zakład Psychodermatologii Uniwersytetu Medycznego w Łodzi, Polska
}

Dermatol Rev/Przegl Dermatol 2019, 106, 92-94 DOI: https://doi.org//0.5। |4/dr.2019.83447

Living with psoriasis can be quite burdensome for the afflicted person. Not only do people face this chronic inflammatory disorder in the form of painful skin impairments [1], but also $17 \%$ of psoriasis patients are known to suffer from anxiety disorders [2]. While low concentrations of dehydroepiandrosterone sulfate (DHEA-S) are found to provoke skin diseases [3], patients with anxiety disorders are also known to have lower concentrations of DHEA-S [4]. Having to face psoriasis on two fronts (physical and psychological) makes the treatment more difficult, as treating one does not always treat the other. Listening to classical music has shown promising results in the form of alleviating anxiety [5] and increasing DHEA-S [6].

Measuring the effects of listening to classical music on DHEA-S levels and subjective anxiety was performed in the dermatology department at the Central Clinical Hospital of Military Institute of Medicine in Warsaw. Twenty-seven female patients aged 21-69 signed a consent form and participated in the experiment. Applied exclusion criteria were smoking and pregnancy because they affect hormone concentrations $[7,8]$. A total of 12 Sarstedt Salivettes were collected from patients, evenly separated over the control and experiment day. Moreover, collections were made during three sets on both days (morning, afternoon and evening together with 30 minutes after each point). During day 2, a preselected list of classical music was administered during those 30 minutes
Życie z łuszczycą może wiązać się ze znacznymi uciążliwościami. U osób z tą przewlekłą chorobą zapalną występują nie tylko bolesne zmiany skórne [1], lecz także zaburzenia lękowe (u 17\% chorych) [2]. Wykazano, że małe stężenia siarczanu dehydroepiandrosteronu (DHEA-S) wywołują choroby skóry [3], ale jego zmniejszone stężenie stwierdza się również u pacjentów z zaburzeniami lękowymi [4]. Konieczność leczenia łuszczycy w dwóch obszarach (fizycznym i psychologicznym) utrudnia postępowanie, ponieważ interwencje dotyczące jednego obszaru nie zawsze przynoszą poprawę w drugim. Stwierdzono, że słuchanie muzyki klasycznej daje obiecujące wyniki w postaci łagodzenia niepokoju [5] i wzrostu stężenia DHEA-S [6].

Ocenę wpływu muzyki klasycznej na stężenie DHEA-S oraz subiektywny poziom lęku przeprowadzono w Klinice Dermatologicznej Wojskowego Instytutu Medycznego z Centralnym Szpitalem Klinicznym w Warszawie. Łącznie 27 pacjentek w wieku 21-69 lat podpisało formularz świadomej zgody i wzięło udział w badaniu. Kryteria wyłączenia obejmowały palenie tytoniu i ciążę, ponieważ należą one do czynników oddziałujących na stężenie hormonów [7, 8]. Przy wykorzystaniu probówek Salivette firmy Sarstedt od każdej pacjentki pobrano 12 próbek równomiernie rozłożonych pomiędzy dzień kontrolny i doświadczalny. Pobieranie próbek $\mathrm{w}$ tych obu dniach odbywało się w trzech punktach 
(in between saliva measurements). Anxiety levels were measured twice (before and after the experiment) using the State Trait Anxiety Inventory (STAI) questionnaire.

Our results showed altogether an increase in mean DHEA-S levels, and higher DHEA-S levels in the morning and afternoon after listening to classical music. STAI results showed no significant changes, which can be accounted for by the very short experiment period. It would be of interest to extend the length of the experiment to measure the effects on the anxiety levels as well.

The aim of this paper was to suggest that listening to classical music might be an additional technique that can be taken into account in the treatment of psoriasis. Previous studies have shown that classical music increases DHEA-S concentration [6] and reduces anxiety levels [5], but no results have been obtained concerning psoriasis patients. Adding classical music, as a routine to a daily schedule, can bring no harm, yet may be of some solace for the patient both physically and psychologically.

To conclude, listening to classical music is a simple, non-invasive and cost-effective technique that can be used as an additional form of treatment for psoriasis.

\section{ACKNOWLEDGMENTS}

The study was approved by the Ethics Committee of the medical University of Lodz with the number RNN 159/13/KE.

Prof. Joanna Narbutt i Prof. Anna Zalewska-Janowska equally contributed to the study.

We thank the Dermatology Department at the Central Clinical Hospital of the Military Institute of Medicine in Warsaw for the possibility to recruit our patients.

Funding sources: The Medical University of Lodz, Young researcher's grant $n * 502-03 / 1-137-04 / 502-14-$ 166.

\section{CONFLICT OF INTEREST}

The authors declare no conflict of interest. czasowych (rano, po południu i wieczorem oraz 30 minut po każdym punkcie czasowym). W 2. dniu pacjentki słuchały przez 30 minut utworów muzyki klasycznej według opracowanej wcześniej listy (między kolejnymi pobraniami próbek). Poziom lęku oznaczano dwukrotnie (przed eksperymentem i po) przy wykorzystaniu kwestionariusza State-Trait Anxiety Inventory (STAI).

Wyniki wykazały wzrost średniego stężenia DHEA-S i zwiększone stężenie tego związku rano oraz po południu po wysłuchaniu muzyki klasycznej. Nie stwierdzono natomiast istotnych zmian wyników uzyskanych w kwestionariuszu STAI, co można wyjaśnić bardzo krótkim czasem trwania badania. Zasadne byłoby wydłużenie okresu obserwacji, aby zmierzyć także wpływ na poziom lęku.

Celem pracy było zbadanie, czy muzykę klasyczną można uznać za dodatkową metodę terapeutyczną w łuszczycy. Wcześniejsze badania wykazały, że muzyka klasyczna zwiększa stężenie DHEA-S [6] i obniża poziom lęku [5], jednak nie było wyników badań dotyczących pacjentów z łuszczycą. Wprowadzenie słuchania muzyki klasycznej jako elementu codziennego postępowania nie przynosi pacjentom żadnej szkody, natomiast może poprawiać ich stan fizyczny i psychologiczny.

Podsumowując - słuchanie muzyki klasycznej jest prostą, nieinwazyjną i efektywną kosztowo metodą, która może być wykorzystywana jako terapia uzupełniająca w leczeniu łuszczycy.

\section{PODZIĘKOWANIA}

Badanie otrzymało zgodę Komisji Bioetycznej przy Uniwersytecie Medycznym w Łodzi (nr RNN 159/13/KE).

Prof. Joanna Narbutt i prof. Anna Zalewska-Janowska mają równy wkład w publikację.

Dziękujemy Klinice Dermatologicznej Wojskowego Instytutu Medycznego z Centralnym Szpitalem Klinicznym w Warszawie za możliwość rekrutacji pacjentek do badania.

Źródło finansowanie: Uniwersytet Medyczny w Łodzi, grant dla młodych naukowców nr 502-03/ 1-137-04/502-14-166.

\section{KONFLIKT INTERESÓW}

Autorzy nie zgłaszają konfliktu interesów.

\section{References \\ Piśmiennictwo}

1. Baurecht H., Hotze M., Brand S., Buning C., Cormican P., Corvin A., et al.: Genome-wide comparative analysis of atopic dermatitis and psoriasis gives insight into opposing genetic mechanisms. Am J Hum Genet 2015, 96, 104-120.

2. Dalgard F.J., Gieler U., Tomas-Aragones L., Lien L., Poot F., Jemec G.B.E., et al.: The psychological burden of skin diseases: a cross-sectional multicentre study among dermatological out-patients in 13 European countries. J Invest Dermatol 2015, 135, 984-991. 
3. Kasperska-Zajac A.: Does dehydroepiandrosterone influence the expression of urticaria? A mini review. Inflammation 2011, 34, 362-366.

4. Gill J., Vythilingam M., Page G.G.: Low cortisol, high DHEA, and high levels of stimulated TNF alpha, and IL-6 in women with PTSD. J Trauma Stress 2008, 21, 530-539.

5. Nomura S.: Effect of music on the secretion of salivary cortisol after the removal of short-term stressful task. J Med Inform Technol 2009, 13, 19-22.

6. McCraty R., Barrios-Choplin B., Rozman D., Atkinson M., Watkins A.: The impact of a new emotional self-management program on stress, emotions, heart rate variability, DHEA and cortisol. Integr Psych Behav 1998, 33, 151-178.

7. Mello N.K.: Hormones, nicotine, and cocaine: clinical studies. Horm Behav 2010, 58, 57-71.

8. Labrie F.: Adrenal androgens and intracrinology. Semin Reprod Med 2004, 22, 299-309.

Received: 16.03 .2018

Accepted: 28.12 .2018

Otrzymano: $16.03 .2018 \mathrm{r}$.

Zaakceptowano: $28.12 .2018 \mathrm{r}$.

Krasiński-Heringa O., Owczarek W., Kozłowska M., Ograczyk-Piotrowska A., Bednarski I., Zalewska-Janowska A., Narbutt J.: The effects of listening to classical music on dehydroepiandrosterone sulfate and subjective anxiety levels in female in-patients with psoriasis. Dermatol Rev/Przegl Dermatol 2019, 106, 92-94. DOI: https://doi.org/10.5114/dr.2019.83447. 